\title{
A multiple error-correction model of housing supply
}

Article

Accepted Version

Stevenson, S. and Young, J. (2014) A multiple error-correction model of housing supply. Housing Studies, 29 (3). pp. 362379. ISSN 1466-1810 doi: https://doi.org/10.1080/02673037.2013.803040 Available at https://centaur.reading.ac.uk/35449/

It is advisable to refer to the publisher's version if you intend to cite from the work. See Guidance on citing.

Published version at: http://www.tandfonline.com/doi/abs/10.1080/02673037.2013.803040\#.UpxX9MTIbMg To link to this article DOI: http://dx.doi.org/10.1080/02673037.2013.803040

Publisher: Routledge

All outputs in CentAUR are protected by Intellectual Property Rights law, including copyright law. Copyright and IPR is retained by the creators or other copyright holders. Terms and conditions for use of this material are defined in the End User Agreement.

\section{www.reading.ac.uk/centaur}

\section{CentAUR}

Central Archive at the University of Reading

Reading's research outputs online 


\section{A Multiple Error-Correction Model of Housing Supply}

Article

Accepted Version

A Multiple Error-Correction Model of Housing Supply

Stevenson, S. and Young, J. (2014) A Multiple Error-Correction Model of Housing Supply. Housing Studies, 29 (3). pp. 362379. ISSN 1466-1810 doi: 10.1080/02673037.2013.803040 Available at http://centaur.reading.ac.uk/40900/

It is advisable to refer to the publisher's version if you intend to cite from the work.

Published version at: http://dx.doi.org/10.1080/02673037.2013.803040

To link to this article DOI: http://dx.doi.org/10.1080/02673037.2013.803040

Publisher: Routledge

All outputs in CentAUR are protected by Intellectual Property Rights law, including copyright law. Copyright and IPR is retained by the creators or other copyright holders. Terms and conditions for use of this material are defined in the End User Agreement.

$\underline{\text { www.reading.ac.uk/centaur }}$

\section{CentAUR}

Central Archive at the University of Reading 
Reading's research outputs online 


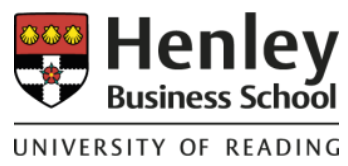

\section{A Multiple Error-Correction Model of Housing Supply}

Accepted for publication in Housing Studies

Simon Stevenson (University of Reading) \& James

Young (University of Auckland) 


\title{
A Multiple Error-Correction Model of Housing Supply*
}

\author{
Simon Stevenson, University of Reading ${ }^{\dagger}$ \\ $\&$ \\ James Young, University of Auckland
}

\begin{abstract}
This paper considers supply dynamics in the context of the Irish residential market. The analysis, in a multiple error-correction framework, reveals that whilst developers did respond to disequilibrium in supply, the rate of adjustment was relatively slow. In contrast, however, disequilibrium in demand did not impact upon supply, suggesting that inelastic supply conditions could explain the prolonged nature of the boom in the Irish market. Increased elasticity in the later stages of the boom may have been a contributory factor in the extent of the house price falls observed in recent years.
\end{abstract}

\footnotetext{
* The valuable comments of the Managing Editor and two anonymous referees are much appreciated. The authors would also like to thank the participants at the Asian Real Estate Society Annual Conference where an early draft of this paper was presented at.

${ }^{\dagger}$ Author to whom correspondence should be addressed: School of Real Estate \& Planning, Henley Business School, University of Reading, Whiteknights, Reading, RG6 6UD, UK. Tel: +44-118-378-4008, email: s.a.stevenson@ reading.ac.uk

* Department of Property, University of Auckland, email: james.young@auckland.ac.nz
} 


\section{A Multiple Error-Correction Model of Housing Supply}

\section{1: Introduction}

In comparison to the large amount of research that has been conducted examining the price dynamics of housing markets, the econometric analysis of supply is relatively sparse. Yet the role of supply in the behaviour of house prices is an immensely important issue and one that has taken on a heightened role given the nature of the last housing cycle observed in a number of markets ${ }^{1}$. Whilst financing issues obviously has grabbed the majority of attention, especially the subprime crisis in the United States, the role of supply also played a key role in the dynamics of housing markets. As Glaeser et al. (2008) recently illustrated, the relative elasticity present in housing markets is importance in the context of speculative behaviour. If markets are characterised by inelastic supply then the impact of increased demand will be concentrated in price behaviour. Therefore, where supply is highly inelastic, or indeed fixed in the short-term, rational bubbles can be observed. This is not however the case when supply displays greater elasticity. In this case the enhanced elasticity may dampen the rationale for bubbles due to the greater availability of new construction (Ball et al., 2010).

However, greater elasticity can have a number of other implications for housing markets and price dynamics. Firstly, it may lead to more irrational and exogenous behaviour in price dynamics; a situation where prices are driven more by expectations concerning future changes in values. It has long been a feature of the housing economics literature that participants in the housing market may display extrapolative or adaptive expectations that rely extensively on recent price history (Poterba, 1991). In addition, it can also be argued that myopic expectations also play a role where participants may fail to anticipate or account for potential reversals in price trends (Malpezzi \& Wachter, 2005). Given this reliance on past history, the role played by adaptive expectations can be linked to myopic behaviour (Case \& Shiller, 1988). The second implication of increased elasticity, as noted by Glaeser et al. (2008), is that the ability of developers to respond more rapidly to increased demand can lead to a shortening of a housing boom. Indeed, Glaeser et al. (2008) show that whilst the average life of boom conditions was in excess of four years in inelastic markets, this shortened to 1.7 years in more elastic ones ${ }^{2}$. Papers such as Goodman \& Thibodeau (2008) and Ellis (2011) note that the recent US cycle has highlighted that some of those markets experiencing the most extreme price movements were those that also witnessed elastic supply responses. This finding leads to a final implication that increased elasticity can increase the risk of subsequent over-supply. This issue is concerned with two elements; firstly, the inherent nature of increased elasticity and secondly, a reduction in the time-span of cyclical behaviour in a market. 
This paper examines the dynamics of housing supply in the context of the Irish market. The Irish market provides an ideal situation in which to consider the interaction of supply with housing price behaviour. The market has witnessed extreme movement over the past 15 years, as represented in Figure's 1 and 2. From the mid-nineties until late 2006 the market saw sustained increases in house prices. From the first quarter of 1994 until the third quarter of 2006, the peak in many markets, average second hand and new nominal house prices increased by $455 \%$ and $323 \%$ respectively on a national basis, while the corresponding figures for Dublin were 553\% and 425\%. Whilst not directly considered in this paper, one consequence arising from this strong house price appreciation was with respect to affordability, where there were parallels with the situation that came into being in the UK (Meen, 2011). As has been common in other markets, rather different conditions have been prevalent over the late part of the last decade with substantial price falls in both new and second hand house prices across the country. However, not only did the Irish market witness substantial movements in price, but in addition, housing construction also displayed extreme cyclical behaviour. Housing completions rose from an average of 28,422 in the nineties to a peak of 89,000 in 2006. As the paper will note, in the initial stages of the housing boom supply was relatively inelastic, a situation that changed dramatically in the later stages of the boom. The changing nature of supply may aid in explaining the dynamics of the Irish housing market during this period.

This paper aims to consider the dynamics of both housing demand and supply using a multiple error-correction model based on the framework of DiPasquale \& Wheaton (1994) and used in a housing supply context by Riddel (2000, 2004). The modelling approach incorporates not only disequilibrium in supply but also allows for disequilibrium in housing prices to impact upon the provision of new stock. Likewise, disequilibrium in stock is allowed to impact upon the dynamics of house prices. This approach differs from that commonly used in the analysis of supply. The majority of the early papers to have modelled housing supply did so without direct consideration of the impact of disequilibrium in house price dynamics (e.g. Topel \& Rosen, 1988; Lee, 1992; Hakfoort \& Matysiak, 1997 and Tse et al., 1999). Whilst later papers such as Barot (2011) did adopt an error-correction framework they did not allow interlinkages between the demand and supply models. Kim \& Coulson (1999) do illustrate the interlinkages, albeit in a different modelling framework. Using a Vector Autoregressive (VAR) model they illustrate that supply shocks play an important role in the behaviour of house prices. In the short-run a shock to housing starts has a positive impact upon prices from the analysis of the Impulse Response functions from the VAR. This makes intuitive sense due to timing issues and that an increase in starts will tend to coincide with 
strong market conditions. However, as the lag length is increased the degree of the impact subsides $^{3}$.

The results in the current paper illustrate the usefulness of considering the interaction of the two components in a modelling framework. We report findings that support the argument that whilst developers and house builders did respond to disequilibrium in supply, they did so at a slow rate of adjustment. We also find that disequilibrium in demand did not significantly impact upon supply. This however is consistent with a view that inelastic supply up until the final stages of the boom aided in prolonging and extending the period of house price appreciation. The remainder of the paper is set out as follows. Section 2 discusses relevant issues relating to both the general supply literature and the specific circumstances of the Irish market. Section 3 presents the models of housing supply and demand used in the paper together with their empirical specifications and details the data used. The empirical results are presented in Section 4 while Section 5 provides concluding comments.

\section{2: Literature Review}

Many of the earlier papers concerning the behaviour of the Irish market over the course of the last two decades illustrated that while prices may have overshot fundamentals, the majority of house price appreciation observed, particularly in the nineties, could be explained through strong economic and demographic trends. Combined with a liberalization of the mortgage market and low interest rates linked to Ireland's membership in the ERM (Exchange Rate Mechanism) and subsequently the single currency, these trends help to facilitate a house price boom. Using the Van Norden (1996) regime-switching model, Roche (1999) estimated that the probability of a crash in the market increased to $2 \%$ in 1998 and that the estimated nonfundamental price was approximately 10\%. Similar results for Dublin were reported in a subsequent analysis (Roche, 2001) which suggested that the probability of a crash had not substantially altered and was only slightly above the national estimates reported in the earlier paper. Stevenson (2008) broadly supported these results, finding that by 2001 and 2002 prices were broadly in line with estimated fundamentals. Indeed, Stevenson (2008) shows that from the fourth quarter 1995 to the end of 2003, while second hand house prices across Ireland rose by $260 \%$, fundamentally based models estimated an increase in prices of at least $162 \%$.

However, these studies considered the earlier stages of the housing boom. Stevenson (2011) updates the analysis contained in Stevenson (2008) to include data up to and including 2009. The error-correction model tested in the paper implies an increasing divergence in prices from fundamentals during the later stages of the boom, reaching a peak of $14 \%$ in 2005. Stevenson 
(2011) also highlights the changing nature of residential construction during the boom, as displayed in Figure 1. It can be seen that whilst construction did increase, it displayed relative inelasticity, particularly when one compares the number of units built during the later period of the boom. It is clear that supply had been fairly constant from the mid-seventies onwards, in the region of 15,000 to 20,000 new private homes each year. The upsurge in demand from the mid-nineties onwards did lead to an increase in new supply, doubling to over 30,000 new private homes by 1996 and to 40,000 by 1999 . Whilst this appears to be a large increase in supply it does need to be placed in context. For example, as a proportion of total stock, Stevenson (2011) notes that the average annual level of new construction during the nineties was actually less than that observed in the eighties, $2.42 \%$ versus $2.44 \%$. While 218,866 new homes were built in the 1995 to 1999 period, the total housing stock only increased by 145,000 due in part to the regeneration projects taking place. Stevenson (2011) further illustrates that much of the new development was not located in Dublin. Indeed, from 1997 onwards, in no single year did Dublin represent more than a quarter of new homes built. This is despite Dublin not only accounting for over a third of the Republic's population, but that the economic and demographic factors at the heart of the housing boom were felt more keenly in the capital city.

However, as Figure 1 illustrates, there was a marked increase in development in the later stages of the housing boom, with annual completions increasing to over 70,000 in 2003 and 2004 and in excess of 85,000 in both 2005 and 2006. Whilst the impact was not to the same proportionate extent, a similar pattern was also observed in the UK during the same period. As Whitehead \& Williams (2011) note, UK completions did not peak until 2007-8 while completions lagged behind the increase in the number of households consistently during the boom period ${ }^{4}$. The argument that supply became more elastic during the later stages of the boom has not been fully considered in the context of the behaviour of the Irish market during this period. While empirical studies of housing supply in Ireland are relatively small in number when compared to those considering price dynamics, those papers that have examined the issue point to supply constraints being present in the late nineties, despite the increase in new construction. Kenny (2003) finds evidence of asymmetric adjustment costs, with the cost of adjustment greater during an expansion in output in comparison to a contraction. Using an asymmetric error-correction model, Kenny's (2003) findings would be supportive of the hypothesis that supply constraints were a key factor in the house price behaviour observed in the Irish market in the late nineties. Stevenson \& Young (2007), in a comparative analysis of house supply forecasts, find evidence that in the mid to late nineties supply did not keep pace with the forecasts produced. 
Stevenson \& Young (2007) argue that a possible reason behind their findings can be addressed by considering the arguments of Spiegel (2001). Spiegel argues that when house prices are rising faster than the rate of interest, developers may delay projects due to the enhanced return potentially available from continuing house price appreciation. Furthermore, given the relationship between land costs and the value of housing, it is also possible that the developer will profit from seeing the value of the site increase. This enhanced profit can therefore offset the gain to be obtained from developing immediately. As a result, this behaviour can lead to supply constraints being observed, particularly during the early stages of a house price boom. This argument can also be related back to the behaviour of market participants in that supply constraints may aid in the explanation of high levels of house price appreciation in response to shocks in demand side variables such as income (Capozza \& Seguin, 1996; Ortalo-Magne \& Rady, 2006). As previously noted, it is generally felt that housing market participants may display extrapolative (Poterba, 1991) and myopic expectations (Malpezzi \& Wachter, 2005). If extrapolative and myopic expectations are dominant across housing markets then the view of Speigel (2001) also extends to the resulting impact on supply though the actions of developers, as further price increases will be encouraged due to constraints on new supply.

Risk aversion can also be viewed as playing a role in the increased inelasticity during booms due to the irreversibility of the real options underpinning the development process. Developers will therefore require additional certainty, or rather reduced uncertainty, before committing to proceeding with a development. Titman (1985) argues that development controls play an important role in the level of uncertainty present and can thus lead to development land being valued to such an extent that development is not economically viable. Mayo \& Sheppard (2001) extend upon this argument and were one of the first papers to argue that the supply curve in housing can be concave and 'bend backwards' during a boom. They argue this is due to planning restrictions, or as they refer to them 'stochastic development control'. In a broader context Pryce (1999) examines the variation in elasticities across housing market cycles. Using a cross-sectional approach he finds evidence that supply across English local authorities displayed greater inelasticity in 1988, a period of appreciating house prices, in comparison to the post-boom period of 1992, when elasticities were greater.

The importance of regulatory constraints in the form of planning is one that a number of studies have considered. Monk \& Whitehead (1996) highlight the importance of planning in the context of land prices, noting that planning will raise the price of land, whilst both Mayo \& Sheppard (1991) and Rosenthal (1999) argue that supply may decrease when vacant or development land prices increase. The impact of regulatory controls can also impact upon the 
elasticity observed, as observed in a large number of papers ${ }^{5}$. For example, Malpezzi \& Mayo (1997) argue that the differences they observe in elasticities in an international context can be related to differences in the stringency of the planning regulations in place with greater inelasticity observed in those countries with heightened restrictions. In a US context, Green et al. (2005) find that all of the cities considered that have stringent zoning regulations display high inelasticity. However, the reverse is not necessarily the case. This is partially attributed to some relaxed markets displaying low growth and/or population loss. In addition, the econometric analysis of Green et al. (2005) finds the regulatory index variable to have a significant negative coefficient with respect to supply elasticity. Further papers to have examined this issue include Mayer \& Sommerville (2000), who illustrate that greater regulation leads to a fall in new construction and a reduced price elasticity and Hwang \& Quigley (2006) who report that greater amounts of regulation have a positive relationship with prices and a negative one with supply. The recent paper by Saiz (2010) finds that even if geographic constraints are accounted for, regulatory constraints continue play an important role. Changes in the regulatory environment can also influence elasticities. Malpezzi (1996) reports that a move from a lightly regulated framework to a more restricted one can lead to an increase in house price by $51 \%$ and furthermore reduce planning permits by $42 \%$.

The importance of regulatory frameworks acting as a constraint on supply cannot be ignored; when there are no constraints it would be expected that responses in supply to upward demand movements should be faster than for downward shifts (Green et al., 2005). The findings of papers such as Kenny (2003), which provides evidence of asymmetric adjustment costs, highlights the importance of considering the impact of such constraints. Indeed, other papers to have empirically modelled Irish housing supply have also illustrated this impact in terms of the rate of adjustment. Both McQuinn (2004) and Addison-Smyth et al. (2008) model Irish housing supply in an error-correction context and find that the error-correction term, with respect to supply, is negative and significant, implying that developers do respond to disequilibrium. However, the findings also illustrate the slow rate of adjustment back to equilibrium, with coefficients of -0.172 and -0.194 respectively.

This view is supported in policy terms by the fact that during the late nineties concerns were being raised with respect to the amount of supply that was being delivered. The Irish Government commissioned three reports (Bacon et al., 1998, 1999; Bacon \& MacCabe, 2000) to consider not only the price appreciation present in the market but also supply issues ${ }^{7}$. The first Bacon report (Bacon et al., 1998) recommended that planning authorities increase residential densities in order to increase supply. It also recommended changes that were intended to help speed up the development process. In addition to concerns over the pace of 
the planning process there were also worries regarding the failure of builders to proceed with developments where planning consent had already been obtained. Therefore, the report recommended that in order to encourage more timely development a $50 \%$ rebate on Capital Gains Tax be introduced for zoned land that was developed within four years. Simultaneously, the Government committed to establish Strategic Development Zones where infrastructure provision and planning processes would be facilitated for residential development in order that developers would face fewer constraints. These actions were meant to provide an incentive for developers to sell land to other firms that had the capacity to develop housing in the near term. The implied threat was that if developers held land undeveloped for too long, then the increased supply resulting from the Strategic Development Zones would dampen their future capital gain. By 2002, however, there was still evidence of significant supply constraints surrounding residential development stemming from the planning system (Williams, et al., 2002). Williams et al. (2002) reported that the supply of land that could be easily and quickly developed was in such short supply that developers were reluctant to sell land holdings for fear that they would not have sufficient plots to continue their own construction activities in the future.

A related issue is concerned with the nature of residential developers in Ireland during this period. Between 1994 and 2003 the Irish homebuilding market was characterised by a large number of small-scale developers who had a limited capacity to produce a large volume of new units. Furthermore, Bacon, et al., (2000) found that even the larger developers, particularly in the Dublin area, faced severe constraints in construction capacity, primarily due to a lack of skilled labour availability ${ }^{8}$. In 2000 it was estimated that 343 firms were engaged in residential development in Ireland, with a capacity equivalent to an average of 140 homes per firm. The emergence of larger developers was still limited in 2000 and it was estimated that the largest developer in the country only had a capacity to build a maximum of 1,500 housing units per year. These figures were in marked contrast to the amount of development land available. Newspaper reports at the time stated that one developer had enough zoned and serviced land to build approximately 9,000 houses in 2000 and that many other home builders had enough land banked to build houses at the same level for the next six years (Cooper, 2000). This suggests that developers may have been holding land in excess of their requirements in order to ensure that there was an adequate supply of zoned and serviced land to continue development into the future. This would have had the additional benefit that a continuing constraint of land supply would have contributed to on-going strength in the price of development land. The implementation of the Strategic Development Zones, which allowed higher densities and fast-track planning for housing development in the peripheral areas of Dublin, was not initiated until 2003. This subsequently allowed and encouraged 
greater supply to enter the market. This can be quite clearly seen in terms of the increase in housing completions noted earlier and displayed in Figures 1 and 2.

\section{3: Empirical Model of Housing Supply}

The modeling approach adopted in this paper is similar in spirit to that used in Riddel (2000, 2004), which in turn builds upon the framework defined by DiPasquale \& Wheaton (1994). The DiPasquale \& Wheaton framework initially defines the long-run equilibrium for stock $\left(\mathrm{S}^{\mathrm{e}}\right)$ as follows, where the long-run equilibrium is a function of house prices $(\mathrm{P})$ and a vector of variables $(\mathrm{X})$ :

$$
S_{t}^{e}=S\left(P_{t}, X_{s, t}\right)
$$

However, the framework allows for stock adjustment from disequilibrium given that it will not occur instantaneously in the context of housing. Therefore, the adjustment can be displayed as follows:

$$
\Delta \mathrm{S}_{\mathrm{t}}=\alpha\left(\mathrm{S}_{\mathrm{t}}^{\mathrm{e}}-\mathrm{S}_{\mathrm{t}-1}\right)
$$

Where $\alpha$ represents the speed of adjustment, a higher figure implying faster adjustment and a lower figure slower movement. Moreover, the DiPasquale-Wheaton framework allows for adjustment from disequilibrium in the context of house prices as well as stock. The equivalent adjustment process with respect to price can be displayed as:

$$
\Delta \mathrm{P}_{\mathrm{t}}=\tau\left(\mathrm{P}_{\mathrm{t}}^{\mathrm{e}}-\mathrm{P}_{\mathrm{t}-1}\right)
$$

Therefore, the modeling framework effectively accounts for the fact that market disequilibrium may occur with respect to both prices and housing stock. Furthermore, the framework allows for disequilibrium in each market to impact upon the other. Given that house prices are taken as a key driver of stock, it is natural to extend the argument that disequilibrium in prices may impact upon supply. Furthermore, as noted previously in the paper with respect to Spiegel's (2001) arguments relating to developer behaviour, disequilibrium in stock may influence house price dynamics. Therefore, we can redefine Equations (2) and (3) as follows: 


$$
\begin{aligned}
& \Delta \mathrm{S}_{\mathrm{t}}=\delta_{1} \varepsilon_{\mathrm{t}-1}+\delta_{2} v_{\mathrm{t}-1}+\mathrm{a}^{\prime} \Delta \mathrm{X}_{\mathrm{t}}+\mu_{1, \mathrm{t}} \\
& \Delta \mathrm{P}_{\mathrm{t}}=\gamma_{1} \varepsilon_{\mathrm{t}-1}+\gamma_{2} v_{\mathrm{t}-1}+\mathrm{b}^{\prime} \Delta \mathrm{X}_{\mathrm{t}}+\mu_{2, \mathrm{t}}
\end{aligned}
$$

Where $\varepsilon_{\mathrm{t}-1}$ is the disequilibrium term with respect to housing demand and $v_{\mathrm{t}-1}$ is the equivalent term with regard to supply. Effectively, this adjustment framework is a multiple error-correction framework. This approach has not only be used in the context of housing supply by Riddel (2000, 2004), but by other papers in a real estate setting (Stevenson, 2007). McQuinn (2004) uses a similar framework in his analysis of house price dynamics in the Irish market. While a formal examination of supply was not undertaken, the error-correction term from a long-run supply model was introduced into the house price ECM model.

The long-run models used are conventional log-level models. The long-run demand model is an inverted demand model, which has been used extensively in the European housing economics literature (e.g. Muellbauer \& Murphy, 1997), and specifically in recent papers of the Irish market (McQuinn, 2004, Stevenson, 2008). Likewise, the long-run supply model is a conventional log-level specification. The empirical version of the supply model can be displayed as:

$$
\ln \mathrm{HC}_{\mathrm{t}}=\alpha_{1}+\beta_{1} \ln \mathrm{HP}_{\mathrm{t}}+\gamma_{1} \ln \mathrm{BC}_{\mathrm{t}}+\chi_{1} \mathrm{r}_{\mathrm{t}}+v_{\mathrm{t}}
$$

Where HC represents housing completions, HP is real house prices, BC is real building costs and $\mathrm{r}$ is the real after-tax interest rate. The data used in this paper is quarterly and covers the period Quarter 21978 through Quarter 2 2008. The completion figures, the house price series and estimates of building costs were obtained from the quarterly Housing Statistics Bulletin of the Department of the Environment, Heritage \& Local Government (DoEHLG). The supply data used is based on private completions and therefore excludes public authority housing. Real after-tax interest rates were estimated in a similar manner to Abraham \& Hendershott (1996). Grimes \& Aitken (2010) find that supply responses are reduced and house price responses are exacerbated as land prices increase. Given these arguments it would have been preferable if an estimate of land costs could have been included in the empirical framework. However, the lack of reliable land prices that were comparable to the scope and coverage of the housing data precluded its inclusion.

The empirical version of the inverted demand model to represent the long-run equilibrium house price is defined as: 


$$
\ln \mathrm{HP}_{\mathrm{t}}=\alpha_{1}+\beta_{1} \ln \mathrm{POP}_{\mathrm{t}}+\gamma_{1} \ln \mathrm{RDI}_{\mathrm{t}}+\lambda_{1} \ln \mathrm{HS}_{\mathrm{t}}+\chi_{1} \mathrm{r}_{\mathrm{t}}+\varepsilon_{\mathrm{t}}
$$

Where HP is real house prices, POP is population (25-44), RDI is real disposable income per capita, HS is the per capita housing stock and $r$ is the real after-tax interest rate. The population and income figures were obtained from the Irish Central Statistics Office (CSO) and per capita housing stock figures were based on data from both the CSO and the DoEHLG.

The lagged residuals from the long-run supply and demand models act as the measure of the divergence from long-term equilibrium. Therefore, the error-correction specifications for the two models can be displayed as illustrated below.

$$
\begin{aligned}
& \Delta \ln \mathrm{HC}_{\mathrm{t}}=\alpha_{1}+\beta_{1} \Delta \ln \mathrm{NHP}_{\mathrm{t}}+\gamma_{1} \Delta \ln \mathrm{BC}_{\mathrm{t}}+\chi_{1} \Delta \mathrm{r}_{\mathrm{t}}+\delta_{1} \varepsilon_{\mathrm{t}-1}+\delta_{2} v_{\mathrm{t}-1}+\xi_{\mathrm{t}} \\
& \Delta \ln \mathrm{HP}_{\mathrm{t}}=\alpha_{1}+\beta_{1} \Delta \ln \mathrm{POP}_{\mathrm{t}}+\gamma_{1} \Delta \ln \mathrm{RDI}_{\mathrm{t}}+\lambda_{1} \Delta \ln \mathrm{HS}_{\mathrm{t}}+\chi_{1} \Delta \mathrm{r}_{\mathrm{t}} \\
& +\delta_{1} \varepsilon_{\mathrm{t}-1}+\delta_{2} v_{\mathrm{t}-1}+\omega_{\mathrm{t}}
\end{aligned}
$$

The nature of the data used in this paper, with regard to both completions and house prices, does however necessitate adjustments to these models given that quarterly data is used throughout the analysis. The housing completions data does display distinct seasonal trends. In addition, issues also arise with the house price data. The housing price data used in this study are the DoEHLG average house price indices. These are based on simple averages of prices on mortgaged properties. The data is not weighted in any form and is therefore also subject to seasonalities. For this reason in both the long-run and ECM models for both supply and demand, seasonal dummy variables are included in the models. Given that all four quarterly dummy variables cannot be included as it would lead to perfect multicolllinearity, one has to be excluded. For the purposes of this paper the fourth quarter is selected as the omitted dummy. As with all such groups of dummy variables, the coefficients estimated relate to the omitted dummy.

\section{4: Empirical Results}

Prior to the presentation of the main long and short-run results, we consider the stationarity of the variables used and examine whether there is evidence of cointegration amongst the variables. The consideration of these two issues is inter-related. As has long been established, since papers such as Granger (1981), the modelling of non-stationary data in a time series 
context may lead to spurious results. In addition, when a linear combination of two series' is $\mathrm{I}(0)$, even if each individual series is $\mathrm{I}(1)$, then the series is said to be cointegrated, thus sharing a common long-term trend. In such a case it is necessary to incorporate an errorcorrection term in any model of the first differenced series'. As noted in the preceding section, the residual from the long-run model, is used as the error-correction term in the shortrun specifications.

Table 1 details the results from two alternative unit root tests to consider whether each of the variables used are stationary. The first tests used is the variation of the Augmented DickeyFuller unit root test proposed by Elliot, Rothenberg \& Stock (1996). It is similar in form to the standard ADF test with the exception that the time-series in question is transformed via GLS (Generalized Least Squares). Papers such as Elliot et al. (1996) argue that this transformation provides the test with significantly greater power than the conventional Dickey-Fuller test. The second unit root test utilised is the Philips-Perron non-parametric test. This is estimated as follows. The standard non-augmented Dickey-Fuller equation is estimated but the t-statistic of the $\alpha$ coefficient is modified in a manner that ensures that autocorrleation does not affect the asymptotic distribution of the test statistic. The results shown in Table 1 relate to the first difference of the series, in each case the level of the series' did not provide significant test statistics. The results show that in all but one case, real disposable income per capita, both unit root tests provide evidence that the series' are I(1). With respect to the real disposable income series, whilst the GLS-ADF does not report significant findings for the first difference, the Philips-Perron test does so.

Table 2 reports the findings from the Johansen cointgeration test. This test is run twice, firstly with those variables used when modelling housing supply (construction, new house prices, building costs, interest rates) and secondly with those series incorporated in the demand models (house prices, 24-44 population, disposable income, housing stock and interest rates). Therefore, given the difference in the number of variables included in each the number of null hypotheses relating to the trace and maximum eigenvalue statistics does differ. However, in both cases the results shown in Table 2 illustrate that there is evidence that the null hypothesis of no cointegrating relationship can be rejected. In both cases however, no further significant results are reported with respect to either test statistic. These findings provide support behind the use of an error-correction framework in the modelling process.

The results from the estimation of the long-run equilibrium supply and demand models are reported in Table 3. The results in both cases are intuitive, with the majority of the coefficients being of the anticipated sign and significant at conventional levels. With regard to 
the supply model house prices have the expected positive relationship with supply. Likewise, building costs have a significant negative coefficient with respect to supply. The only one of the vector of variables that is not significant at conventional levels is interest rates. This is possibly due to the position of Ireland within the Eurozone and the fact that interest rates are now set at a European level by the European Central Bank. This has led to situations occurring in an Irish context where rates have diverged from what perhaps would have been set previously by the Irish Central Bank. In particular, in 2001 there was a period of negative real interest rates. In relation to the demand model reported, it can be seen that the demographic and wealth factors have the expected positive impact on real house prices and are significant at conventional levels. Furthermore, per capita housing stock is significant and of the anticipated negative sign. As with the long-run supply model interest rates are not statistically significant.

Table 4 presents the results from the two multiple error-correction models. It is noticeable that in the majority of cases the fundamental variables fail to achieve levels of statistical significance. Given the sample period used in the study, this is perhaps illustrative of the extreme price movements and shifts in housing completions. The only fundamental variable that is statistically significant is real disposable income per capita in the demand ECM model. While population and housing stock in the demand equation and house prices and building costs in the supply model are all of the anticipated signs, in no case are they significant at conventional levels. Whilst this can be explained, it should be noted that in comparison to Stevenson (2011) there is a relative lack of significant findings.

With respect to the error-correction terms the results highlight the impact of disequilibrium and the adjustment process. In the supply model the measure of supply disequilibrium is significant, implying that developers do indeed respond to shifts in the long-run equilibrium. Furthermore, the coefficient is negatively signed. Therefore, when housing supply is above its long-run equilibrium we obtain the anticipated negative response, i.e. a reduction in supply. The reverse situation therefore occurs when supply is below equilibrium, with an increase in supply following. This is similar to the findings of both McQuinn (2004) and Addison-Smyth et al. (2008) who estimate ECM models of Irish housing supply.

The demand disequilibrium term is not significant in the case of the supply ECM model. The findings imply that if a situation occurred whereby house prices were above their long-term equilibrium, then a significant response in supply would not be observed. Comparisons with previous empirical research on the Irish market are not possible as neither McQuinn (2004) nor Addison-Smyth et al. (2008) included such a term in their supply models. However, the 
results are consistent with the findings of Riddel $(2000,2004)$ with respect to the US market. As with the current paper, Riddel found that while developers responded to disequilibrium in supply they do not respond to demand disturbances. This is of interest given that expectations of future house prices will be key elements in any developer's assessment of the profitability of a scheme. Riddel (2004) notes that her use of aggregate data across both small and large developers and across the US, may mask the response of some developers to disequilibrium in house prices. However, the use of data from such a smaller economy as Ireland does reduce the relevance of this point and therefore makes the findings in the current study of further interest. In addition, Riddel (2000), when analysing the market of Boulder, Colorado, also found similar results. The lack of a significant response can be viewed as being consistent with Speigel's (2001) argument relating to developer behaviour. If developers did indeed refrain from increasing supply, even in the light of prices overshooting their long-run equilibrium, this may be due to them viewing that potentially even higher profits were available in the future. The presence of extrapolative expectations on the part of housing market participants would also add to this. In addition, it is also consistent with the findings of papers such as Mayo \& Sheppard (2001) with respect to a concave supply curve and the empirical results of Pryce (1999) in terms of increased price inelasticity in boom conditions. In addition, the previously noted constraints on developers capability to deliver large quantities of new supply as needs to be considered as a possible explanation.

To further examine this issue it is of interest to consider the findings from the demand ECM model. As would be expected, the demand error-correction term is significant and of the anticipated negative sign. Whilst expected this is of interest from a number of perspectives. Firstly, it illustrates that irrespective of the strong movement in house prices in the Irish market over the last fifteen years, prices did respond to demand based disequilibrium. These are similar findings to those reported by McQuinn (2004) and Stevenson $(2008,2011)$ in their demand ECM estimations of the Irish market. Furthermore, as Riddel $(2000,2004)$ notes, if supply does not respond to demand shocks, it would be expected that the response would be observed with respect to prices. Although, as with the findings of Riddel, the rate of adjustment is relatively slow. In the current paper the coefficient of -0.0997 can be interpreted in the context of a $9.97 \%$ price adjustment per quarter in response to disequilibrium. Therefore, only $9.97 \%$ of the required price adjustment necessary to return to equilibrium has occurred. Even though demand disequilibrium does significantly impact upon price movements, the slow rate of adjustment means that the results are not inconsistent with those papers to have observed prices substantially above fundamental levels. 
Interestingly, the supply error-correction term is also significant in the demand ECM model, although at a marginal level. However, this is in contrast to Riddel (2004) and McQuinn (2004), though similar to the findings of Riddel (2000). Furthermore, the term has a positive sign, with a coefficient of 0.0328 . One explanation for this may be found in the differing myopic expectations of home purchasers and developers on future price movements. Glaser et al. (2008) suggest that in markets where housing supply is inelastic housing price bubbles tend to be more pronounced and tend to have a longer duration. This is in comparison to the situation in markets where supply is relatively elastic. While Glaser, et al. (2008) focused upon geospatial constraints and building permits to measure housing supply inelasticity in response to price, the results obtained in this analysis suggest that delays in planning may act similarly in extending house price bubbles. This can also be felt to be supported by Ball et al. (2010) who found that historical patterns surrounding land use, as well as planning constraints, influence supply elasticities. Between 1999 and 2003, the issue of housing supply and prices were the focus of intense scrutiny in the Irish media, due in part to the numerous reports being produced for the Government and professional bodies. In addition increasing concern was also being voiced in terms of the negative impact upon affordability. Delays in the planning process and infrastructure constraint issues were at the forefront of these reports and could have led to the widespread perception that housing supply could not keep up with demand, driving prices upward in the face of increasing supply. It is in light of these planning constraints and the myopic expectations of home purchasers that a shortage of housing exists, that this positive disequilibrium in supply could lead to a positive impact on prices. Figure 3 graphically displays the disequilibrium terms for supply and demand which are obtained from Equations (8) and (9) respectively. The results would appear to provide support for the notion that supply constraints played a role in the late nineties and possibly aided in an extension of the time frame which witnessed sustained house price appreciation. Likewise, the fact that supply is above its equilibrium level in the later stages of the boom would provide some level of support for the view that increased elasticity perhaps contributed to a shortening of the boom and to the reversal in house prices subsequently observed.

\section{5: Conclusions}

This paper has considered the interaction between disequilibrium in demand and supply in the context of the Irish housing market using a multiple error-correction framework. The empirical model incorporates not only disequilibrium in supply but also allows for disequilibrium in housing prices to impact upon the provision of new stock. Likewise, disequilibrium in stock is allowed to impact upon the dynamics of house prices. The results reveal that whilst developers did respond to disequilibrium in supply, the rate of adjustment 
was relatively slow. In contrast, however, disequilibrium in demand did not impact upon supply, implying inelastic supply conditions. This may aid in explaining the prolonged nature of the boom in the Irish market. In addition, whilst outside the direct scope of this analysis, increased liberalisation in the regulatory framework, and therefore increased elasticity, during the later stages of the boom could in part explain the reversal in market dynamics.

This evidence would be consistent with the arguments made in Glaeser et al. (2008) who find evidence that some markets with relatively elastic supply observed high levels of house price appreciation during the recent US cycles. However, these were relatively short in their duration, suggesting that the increasing prices were more due to expectations (extrapolative and myopic) rather than supply constraints with respect to increased fundamental demand. As they note, the decline in prices following the end of a boom is associated with both an end to over optimistic views regarding future house price appreciation and over supply relating to elastic supply conditions. When supply is inelastic, increased demand is concentrated in terms of its effect upon price dynamics, due to the constraints imposed on supply being able to respond. In elastic markets 'irrational exuberance' may lead to an increase in prices but as supply can respond more rapidly and to a greater extent, the bubble should be shorter, in part due to a failure of house price gains to meet heightened expectations as increased supply of that magnitude will dampen house price appreciation. One possible extension of the current work is to consider how elasticity in the Irish market altered over-time due to the changes in the planning regime in place. 


\section{References:}

Abrahams, J. \& Hendershott, P. (1996). Bubbles in Metropolitan Housing Markets, Journal of Housing Research, 7, 191-208.

Addison-Smyth, D., McQuinn, K. \& O'Reilly, G. (2008). Estimating the Structural Demand for Irish Housing, Research Technical Paper 1/RT/08, Central Bank and Financial Services Authority of Ireland.

Ball, M., Meen, G, \& Nygaard, C. (2010). Housing Supply Price Elasticities Revisited: Evidence from International, National, Local and Company Data, Journal of Housing Economics, 19 (4), 255-268.

Barot, B. (2001). An Econometric Demand-Supply Model for Swedish Private Housing, European Journal of Housing Policy, 1, 417-444.

Berry, J., McGreal, S., Stevenson, S. \& Young, J. (2001). Government Intervention and its Impact on the Housing Market in Greater Dublin, Housing Studies, 16, 755-769.

Blackley, D.M. (1999). The Long-Run Elasticity of New Housing Supply in the United States: Empirical Evidence for 1950-1994, Journal of Real Estate Finance \& Economics, 18, $25-42$.

Bramley, G. \& Leishman, C. (2005). Planning and Housing Supply in Two-Speed Britain: Modelling Local Market Outcomes, Urban Studies, 42, 2213-2244.

Bramley, G., Leishman, C. \& Watkins, D. (2008). Understanding Neighbourhood Housing Markets: Regional Context, Disequilibrium, Sub-Markets and Supply, Housing Studies, 23, 179-212.

Capozza, D.R. \& Seguin, P.J. (1996). Expectations, Efficiency and Euphoria in the Housing Market, Regional Science and Urban Economics, 26, 369-386.

Case, K.E. \& Shiller, R.J. (1989). The Efficiency of the Market for Single Family Homes, American Economic Review, 79, 125-137.

Cooper, M. (2000). Who Owns Dublin ?, The Sunday Tribune, February $20^{\text {th }}$, http://www.tribune.ie/article/2000/feb/20/who-owns-dublin/

D’Agostino, A., McQuinn, K. \& O’Reilly (2008). Identifying and Forecasting House Price Dynamics in Ireland, Research Technical Paper 3/RT/08, Central Bank and Financial Services Authority of Ireland.

DiPasquale, D. \& Wheaton, W. (1994). Housing Market Dynamics and the Future of Housing Prices, Journal of Urban Economics, 35, 1-27.

Duca, J.V., Muellbauer, J. \& Murphy, A. (2010). Housing Markets and the Financial Crisis of 2007-2009: Lessons for the Future, Journal of Financial Stability, 6, 203-217.

Elliot, G., Rothenberg, T.J. \& Stock, J.H. (1996). Efficient Tests for an Autoregressive Unit Root, Econometrica, 64, 813-836.

Ellis, L. (2011). Eight Policy Lessons from the US Housing Meltdown, Housing Studies, 26, $1215-1230$.

Glaser,E. \& Gyourko, J. (2006). Housing Dynamics, NBER Working Paper No. 12787.

Glaser,E., Gyourko, J., \& Saiz, A. (2008). Housing Supply And Housing Bubbles, Journal of Urban Economics, 64), 198-217.

Goodman, A. C. \& Thibodeau, T. G. (2008). Where are the Speculative Bubbles in US Housing Markets?, Journal of Housing Economics, 17, 117-137. 
Green, R.K., Mappezzi, S. \& Mayo, S.K. (2005). Metropolitan Specific Estimates of the Price Elasticity of Supply of Housing and Their Sources, American Economic Review, 95, 334-339.

Granger, C. (1981). Some Properties of Time Series Data and their use in Econometric Model Specification, Journal of Econometrics, 16, 121-130.

Grimes, A. \& Aitken, A. (2010). Housing Supply, Land Costs and Price Adjustment, Real Estate Economics, 38, 325-353.

Hakfoort, J. \& Matysiak, G. (1997). Housing Investment in the Netherlands, Economic Modelling, 14, 501-516.

Hwang, M. \& Quigley, J.M. (2006). Economic Fundamentals in Local Housing Markets: Evidence from US Metropolitan Regions, Journal of Regional Science, 46, 425-453.

Kenny, G. (1999). Modelling the Demand and Supply Sides of the Housing Market: Evidence from Ireland, Economic Modelling, 16, 389-409.

Kenny, G. (2003). Asymmetric Adjustment Costs and the Dynamics of Housing Supply, Economic Modelling, 20, 1097-1111.

Kim, M.S. \& Coulson, N.E. (1999). Sources of Fluctuations in the Housing Market, International Economic Journal, 13, 57-70.

Lee, T. H. (1992). Stock-Flow Relations in US Housing Construction, Oxford Bulletin of Economics and Statistics, 54, 419-430.

McQuinn, K. (2004). A Model of the Irish Housing Sector, Research Technical Paper 1/RT/04, Central Bank and Financial Services Authority of Ireland.

Malpezzi, S. (1996). Housing Prices, Externalities and Regulation in U.S. Metropolitan Areas, Journal of Housing Research, 7, 209-241.

Malpezzi, S. \& MacLennan, D. (2001). The Long-Run Price Elasticity of Supply of New Residential Construction in the United States and the United Kingdom, Journal of Housing Economics, 10, 278-306.

Malpezzi, S. \& Wachter, S.M. (2005). The Role of Speculation in Real Estate Cycles, Journal of Real Estate Literature, 13, 143-166.

Mayer, C.J. \& Sommerville, C.T. (2000). Land use Regulations and New Construction, Regional Science and Urban Economics, 30, 639-662.

Mayo, S. \& Sheppard, S. (2001). Housing Supply and the Effects of Stochastic Development Control, Journal of Housing Economics, 10, 109-128.Meen, G. (2011). A Long-Run Model of Housing Affordability, Housing Studies, 26, 1081-1103.

Meen, G. \& Nygaard, C. (2011). Local Housing Supply and the Impact of History and Geography, Urban Studies, 48, 3107-3124.

Monk, S. \& Whitehead, C.M.E. (1996). Land Supply and Housing: A Case Study, Housing Studies, 11, 407-423.

Muellbauer, J. \& Murphy, A. (1997). Booms and Busts in the UK Housing Market, The Economic Journal, 107, 1701-1727.

Muellbauer, J. \& Murphy, A. (2008). Housing Markets and the Economy: The Assessment, Oxford Review of Economic Policy, 24, 1-33.

Ortalo-Magne, F. \& Rady, S. (2006). Housing Market Dynamics: On the Contribution of Income Shocks and Credit Constraints, The Review of Economic Studies, 73, 459-485.

Poterba, J. (1991). House Price Dynamics: The Role of Tax Policy and Demography, Brookings Papers on Economic Activity, 2, 143-203. 
Pryce, G. (1999). Construction Elasticities and Land Availability: A Two-Stage LeastSquares Model of Housing Supply using the Variable Elasticity Approach, Urban Studies, 13, 2283-2304.

Riddel, M. (2000). Housing Market Dynamics under Stochastic Growth: An Application to the Housing Market in Boulder, Colorado, Journal of Regional Science, 40, 771-788.

Riddel, M. (2004). Housing Market Disequilibrium: An Examination of Housing Market Price and Stock Dynamics 1967-1998, Journal of Housing Economics, 13, 120-135.

Roche, M. (1999). Irish House Prices: Will the Roof Cave in ?, The Economic and Social Review, 30, 343-362.

Roche, M. (2001). The Rise in House Prices in Dublin: Bubble, Fad or just Fundamentals, Economic Modelling, 18, 281-295.

Rosenthal, S. (1999). Residential Buildings and the Cost of Construction: New Evidence on the Efficiency of the Housing Market, Review of Economics and Statistics, 81, 288-302.

Saiz, A. (2010). The Geographic Determinants of Housing Supply, Quarterly Journal of Economics, 125, 1253-1296.

Spiegel, M. (2001). Housing Returns and Construction Cycles, Real Estate Economics, 29, 521-551.

Stevenson, S. (2007). Exploring the Intra-Metropolitan Dynamics of the London Office Market, Journal of Real Estate Portfolio Management, 13, 93-98.

Stevenson, S. (2008). Modelling Housing Market Fundamentals: Empirical Evidence of Extreme Market Conditions, Real Estate Economics, 36, 1-29.

Stevenson, S. (2011). The Dynamics of the Irish Housing Market, in Bardhan, A., Edelstein, R. \& Kroll, C. (Eds.). One World, One Crisis ? The Global Housing Market Meltdown Essays from Around the World, John Wiley \& Sons.

Stevenson, S. \& Young, J. (2007). Forecasting Housing Supply: Empirical Evidence from the Irish Market, European Journal of Housing Policy, 7, 1-17.

Titman, S. (1985). Urban Land Prices under Uncertainty, American Economic Review, 75, 505-514.

Topel, R. \& Rosen, S. (1979). Housing Investment in the US, Journal of Political Economy, 87, 718-740.

Tse, R.Y.C., Ho, C.W. \& Ganesan, S. (1999). Matching Housing Supply and Demand: An Empirical Study of Hong Kong's Market, Construction Management and Economics, 17, 625-633.

Van Norden, S. (1996). Regime Switching as a Test for Exchange Rate Bubbles, Journal of Applied Econometrics, 11, 219-251.

Williams, B., Shiels, P., and Hughes, B. (2002). SCS Housing Study 2002: A Study of Housing Supply and Urban Development Issues in the Dublin Area, Dublin: Society of Chartered Surveyors.

Whitehead, C. \& Williams, P. (2011). Causes and Consequences? Exploring the Shape and Direction of the Housing System in the UK Post the Financial Crisis, Housing Studies, 26, 1157-1169. 


\section{A Multiple Error-Correction Model of Housing Supply}

\section{Tables and Figures}

\section{Figure 1: Housing Completions and Average House Prices}

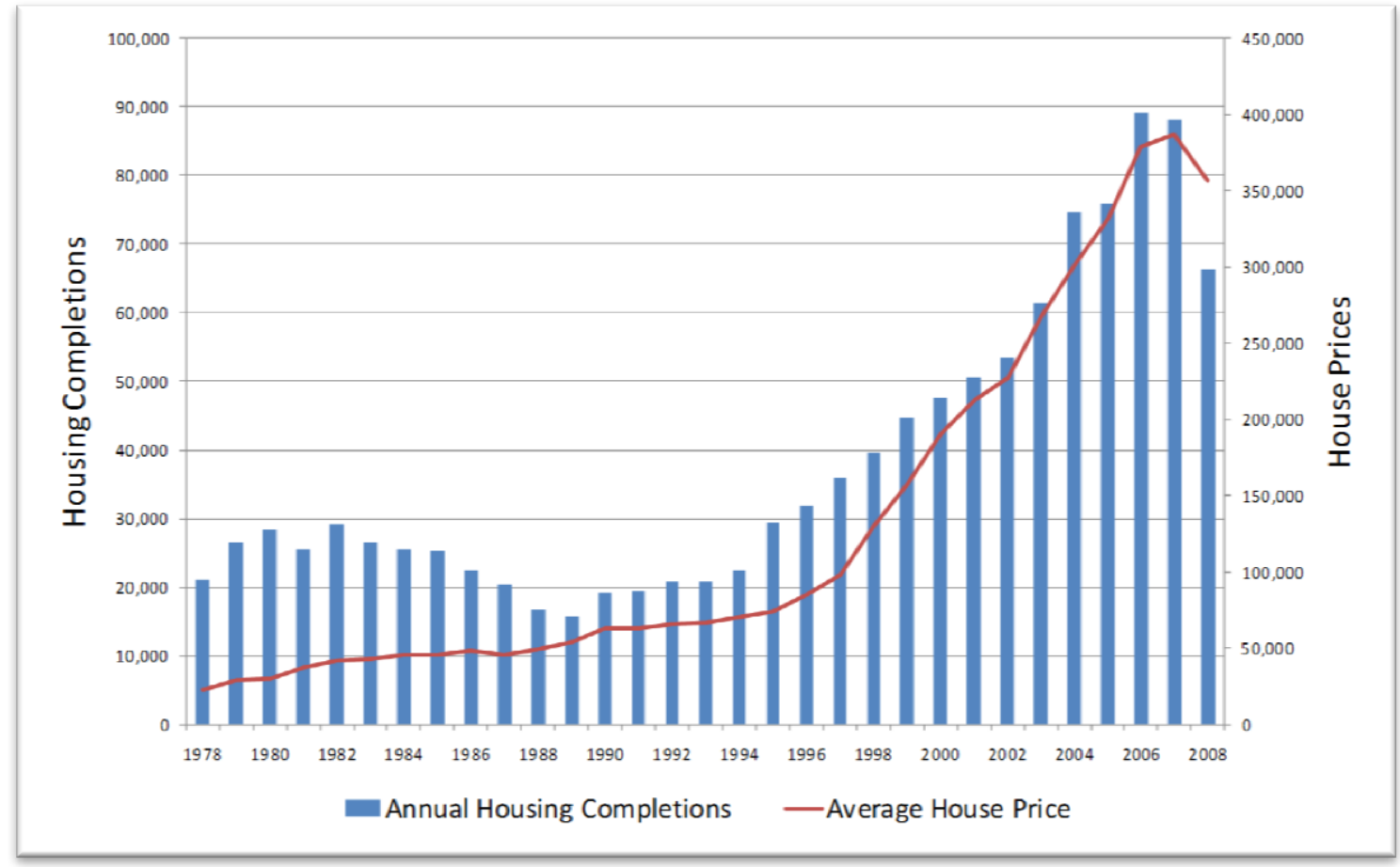

Notes: Figure 1 displays the annual number of private sector completions in the Irish residential sector and the average nominal house price. 
Figure 2: Annual Growth Rates in the Irish Housing Markets, 1978-2008

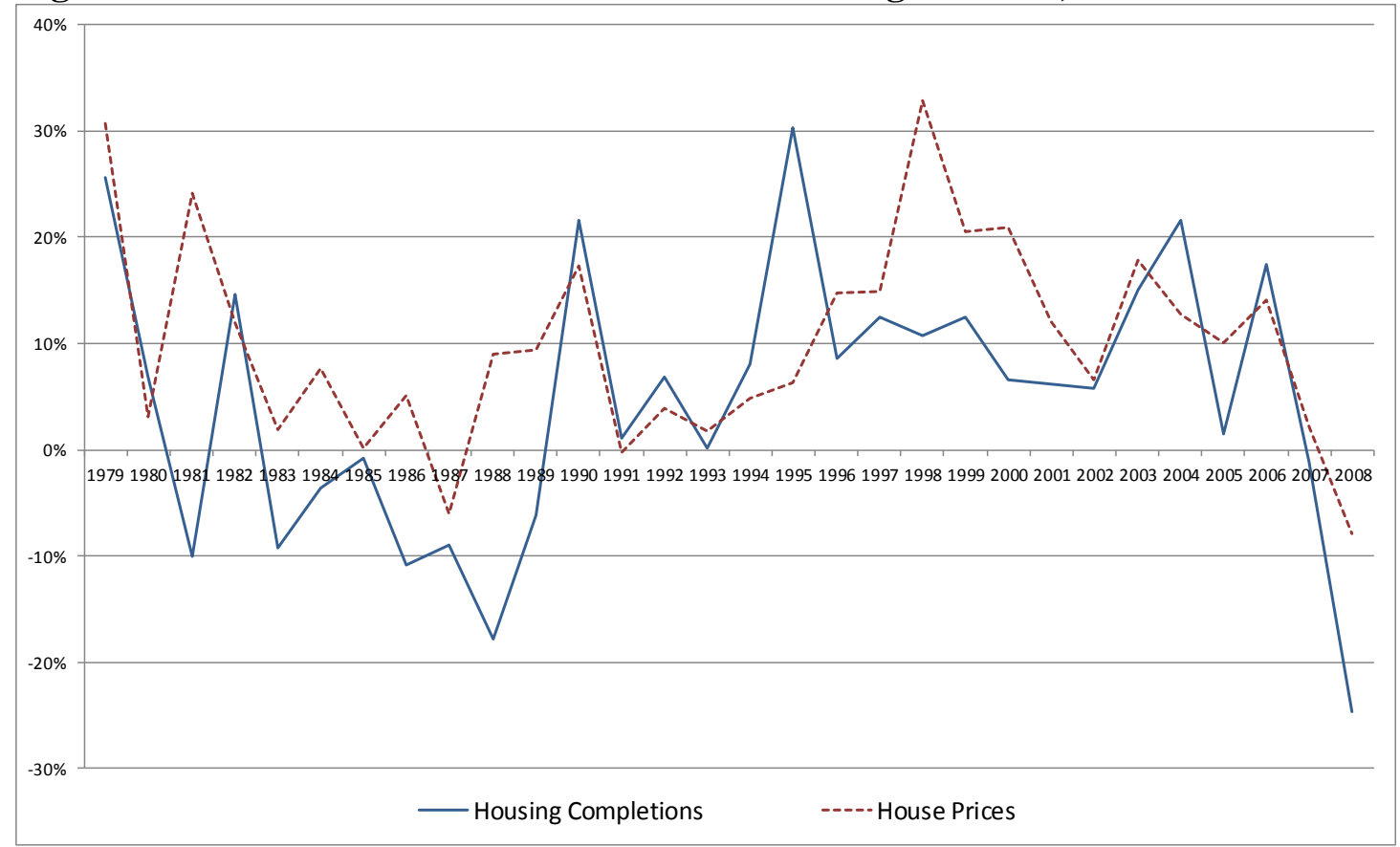

Notes: Figure 2 reports the annual percentage changes in the annual number of private sector completions in the Irish residential sector and average nominal house price. 
Table 1: Unit Root Tests

\begin{tabular}{lcc}
\hline & ERS ADF & PP \\
\hline Housing Completions & $-2.4455^{* *}$ & $-18.2332 * * *$ \\
Real New House Prices & $-1.6541 *$ & $-11.6475 * * *$ \\
Real Building Costs & $-2.7949 * * *$ & $-9.5443 * * *$ \\
Real After Tax Interest Rates & $-2.4508 * *$ & $-8.6575 * * *$ \\
Population 25-44 & $-2.1759 * *$ & $-4.0877 * * *$ \\
Real Disposable Income per Capita & -1.2504 & $-7.2321 * * *$ \\
Per Capita Housing Stock & $-4.9799 * * *$ & $5.1864 * * *$ \\
\hline
\end{tabular}

Notes: Table 1 details the unit root test statistics on the first differenced data for each of the variables used in the empirical analysis. Two alternative unit root tests are used, namely the Elliot-RothenbergStock adaptation of the Augmented Dickey-Fuller test and the Philips-Peron test. * indicates significance at $90 \%, * *$ at $95 \%$ and $* * *$ at $99 \%$.

Table 2: Johansen Cointgegration Tests

\begin{tabular}{lcccc}
\hline Null Hypothesis & Supply Model & \multicolumn{3}{c}{ Demand Model } \\
\hline & Trace & Eigenvalue & Trace & Eigenvalue \\
\hline $\mathrm{r}=0$ & $67.5577^{* * *}$ & $42.3126 * * *$ & $80.0834^{* * *}$ & $38.2407^{* *}$ \\
$\mathrm{r}=1$ & 25.2451 & 17.7621 & 41.8427 & $25.6901^{*}$ \\
$\mathrm{r}=2$ & 7.4830 & 6.1144 & 16.1526 & 10.5944 \\
$\mathrm{r}=3$ & 1.3686 & 1.3686 & 5.5582 & 4.9139 \\
$\mathrm{r}=4$ & N/A & N/A & 0.6443 & 0.6443 \\
\hline
\end{tabular}

Notes: Results from Johansen cointegration tests for the variables used in the supply and demand models are displayed in Table 2.* indicates significance at $90 \%, * *$ at $95 \%$ and $* * *$ at $99 \%$. 
Table 3: Long-Run Supply and Demand Models

\begin{tabular}{lccc}
\hline & Coefficient & Standard Error & T-Statistic \\
\hline Panel A: Supply Model & & & \\
\hline Constant & 2.6926 & 0.4819 & $5.5865^{* * *}$ \\
Real New House Prices & 1.0112 & 0.0534 & $18.9478^{* * *}$ \\
Real Building Costs & -0.1762 & 0.0559 & $-3.1527^{* * *}$ \\
Real After Tax Interest Rates & -0.0421 & 0.0482 & -0.8734 \\
Quarter 1 Dummy & -0.1403 & 0.0424 & $-3.3118^{* * *}$ \\
Quarter 2 Dummy & -0.1441 & 0.0420 & $-3.4315^{* * *}$ \\
Quarter 3 Dummy & -0.0854 & 0.0423 & $-2.0182^{* *}$ \\
Adjusted R & 0.9050 & & \\
\hline Panel B: Demand Model & & & \\
\hline Constant & -35.7941 & 3.2691 & $-10.9492^{* * *}$ \\
Population 25-44 & 1.8184 & 0.2519 & $7.2178^{* * *}$ \\
Real Disposable Income per Capita & 2.5599 & 0.1029 & $24.8575^{* * *}$ \\
Per Capita Housing Stock & -2.1291 & 0.1268 & $-16.7963 * * *$ \\
Real After Tax Interest Rates & 0.0164 & 0.0213 & 0.7727 \\
Quarter 1 Dummy & -0.0175 & 0.0181 & -0.9633 \\
Quarter 2 Dummy & 0.0184 & 0.0179 & 1.0247 \\
Quarter 3 Dummy & 0.0055 & 0.0181 & 0.3029 \\
Adjusted R & 0.9833 & & \\
\hline
\end{tabular}

Notes: Table 3 reports the results from the long-run supply model as specified in Equations 6 and 7. * indicates significance at $90 \%, * *$ at $95 \%$ and $* * *$ at $99 \%$. 
Table 4: Error-Correction Models

\begin{tabular}{lccc}
\hline & Coefficient & Standard Error & T-Statistic \\
\hline Panel A: Supply Model & & & \\
\hline Constant & 0.0878 & 0.0262 & $3.3504^{* * *}$ \\
Real New House Prices & 0.4212 & 0.3451 & 1.2205 \\
Real Building Costs & -0.1228 & 0.6735 & -0.1823 \\
Real After Tax Interest Rates & 0.0345 & 0.0788 & 0.4383 \\
Quarter 1 Dummy & -0.2359 & 0.0343 & $-6.8749^{* * *}$ \\
Quarter 2 Dummy & -0.0644 & 0.0365 & $-1.7641^{*}$ \\
Quarter 3 Dummy & -0.0301 & 0.0339 & -0.8879 \\
Supply Error-Correction Term & -0.3920 & 0.0771 & $-5.0839^{* * *}$ \\
Demand Error-Correction Term & -0.0861 & 0.1856 & -0.4638 \\
Adjusted R & 0.4387 & & \\
\hline Panel B: Demand Model & & & -1.3779 \\
\hline Constant & -0.0104 & 0.0075 & 1.4282 \\
Population 25-44 & 2.1188 & 1.4835 & $5.2608^{* * *}$ \\
Real Disposable Income per Capita & 1.4227 & 0.2704 & -0.1273 \\
Per Capita Housing Stock & -0.0693 & 0.5442 & -1.4843 \\
Real After Tax Interest Rates & -0.0296 & 0.0199 & -1.0120 \\
Quarter 1 Dummy & -0.0086 & 0.0085 & $4.3701 * * *$ \\
Quarter 2 Dummy & 0.0373 & 0.0085 & -0.2037 \\
Quarter 3 Dummy & -0.0018 & 0.0087 & $1.6804 *$ \\
Supply Error-Correction Term & 0.0328 & 0.0195 & $-2.1201 * *$ \\
Demand Error-Correction Term & -0.0997 & 0.0470 & \\
Adjusted R & 0.3854 & & \\
\hline
\end{tabular}

Notes: Table 4 reports the results from the error-correction specification of the supply and demand model as displayed in Equations 8 and 9. * indicates significance at $90 \%$, ** at $95 \%$ and $* * *$ at $99 \%$. 
Figure 3: Supply and Demand Disequilibrium Terms

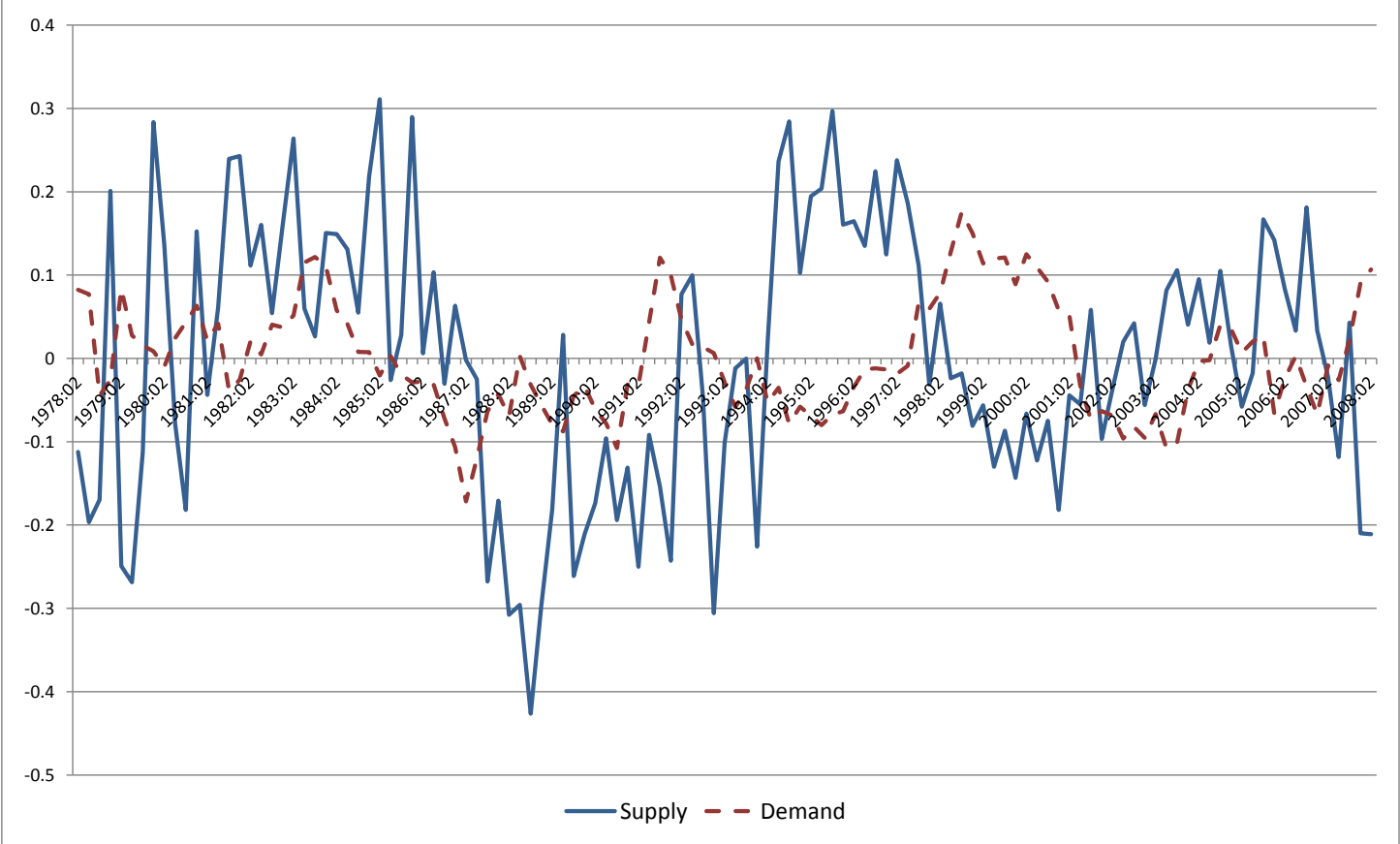

Notes: Figure 3 presents the disequilibrium terms from the respective Error-Correction Models. 


\section{Endnotes:}

${ }^{1}$ For a broad analysis of some of the key elements of the recent cycle in an international context see papers such Duca et al. (2010), Ellis (2011).

${ }^{2}$ See also the recent paper by Grimes \& Aitken (2010). In addition, Glaeser \& Gyourko (2006) note that whilst demand factors still drive mean reverting behaviour in housing markets, the importance of supply side factors is increased in the case of markets with more elastic supply.

${ }^{3}$ In the context of sub-market behaviour Bramley \& Leishman (2005) and Bramley et al. (2008) consider the issue of disequilibrium, factoring into the analysis the links between supply and house price dynamics.

${ }^{4}$ Levin \& Pryce (2009) also consider the impact of constraints upon the inelastic nature of supply during the boom.

${ }^{5}$ Meen \& Nygaard, (2011) argue that regional differences in the supply elasticities can also be associated with variation in historical land use

${ }^{6}$ See also Blackely (1999) for a time series analysis of elasticity. In addition, Malpezzi \& Maclennan (2001) find that elasticity is greater in the United States in comparison to the UK. Furthermore, and whilst elasticity marginally increased in the US post-1945, it has reduced (become more inelastic) in the UK. Muellbauer \& Murphy (2008) argue that greater inelasticity in the UK contributed, together with other factors, to the enhanced cyclical behaviour observed in the UK during the cycle of the late eighties-early nineties.

${ }^{7}$ See Berry et al. (2001) for a consideration of the short-term impact on the Irish housing market from the first Bacon report.

${ }^{8}$ In a broader context, Green et al. (2005) note potential issues with labour demand. They note that increased demand can lead to both labour and material shortages that can lead to subsequent upward pressure on prices. Pryce (1999) also considers the impact of labour constraints. 